\section{Survey confirms fears about licensing of genetic tests}

Sir-S. M. Thomas et al., in their surveys of patents for genetic diseases ${ }^{1,2}$, expressed concern about monopolization by companies of "an entire gene and its mutations for all diagnostic and therapeutic purposes" ${ }^{\text {. }}$. We asked a sample of owners of genetic testing patents about their licensing activities, and here we report that these patents are being exclusively licensed, permitting the monopolization of clinical testing services as Thomas et al. predicted. This result heightens our concerns that these patents may raise costs, curtail access to testing and limit clinical observation, which is fundamental to the practice of medicine $e^{3,4}$.

We identified 37 US patents issued in 1991-97 that broadly cover the diagnosis of human genetic disorders. We excluded two patents held by non-US institutions and two that had expired. These 33 patents were assigned to 19 institutions, 16 public (such as universities) and three private companies. These patents cover tests for neurological diseases (13), cardiovascular diseases (6), metabolic disorders (6), cancers (5) and immunological disorders (3). Of the 33 patents in our analysis, 22 (67\%) were funded at least in part by the US government, a percentage consistent with a previous sample ${ }^{5}$. With approval from our institutional review board, we called patent holders to ask them questions about licensing efforts, marketing of the patent or genetic test, known uses of the test, and enforcement of the patent. In summer 1998, we held 17 interviews covering 27 patents (response rate: $89 \%$ institutions; $82 \%$ patents). One respondent was an inventor and all others were involved in technology transfer or licensing at an assignee institution.

Our survey results are in Table 1. Nine of 14 patents $(64 \%)$ issued more than two years before the date of our survey were licensed, in contrast to 5 of $13(38 \%)$ of those issued more recently (one-sided Fisher's exact, $P=0.17$ ). Tests for which respondents reported known clinical uses were more likely to have been licensed

$(\mathrm{OR}=14.7, z=2.3, P=0.02)$.

Critically, all 14 patent licences were exclusive. Although some authors have predicted that academic institutions would grant non-exclusive licences for patents ${ }^{6}$, these institutions do not have the resources to manage widespread licensing.

Exclusive rights to several of the patents in our sample are being used to monopolize testing services. Further, since our survey, US patents have been issued covering tests

\begin{tabular}{|c|c|c|}
\hline Table 1 Patent survey results & $N$ & $\%$ \\
\hline Patents covered by survey & 27 & \\
\hline \multicolumn{3}{|l|}{ Licensing: } \\
\hline Exclusive licences granted & 14 & 52 \\
\hline Non-exclusive licences granted & 0 & 0 \\
\hline No known interest to take licence & 9 & 33 \\
\hline Licensing in process & 2 & 7 \\
\hline Will not be licensed & 2 & 7 \\
\hline \multicolumn{3}{|c|}{ Promotion and development of patented test: } \\
\hline Active marketing effort & 25 & 92 \\
\hline Not worth effort & 1 & 4 \\
\hline $\begin{array}{l}\text { Not being promoted, no reason given } \\
\text { noting }\end{array}$ & 1 & 4 \\
\hline Test undergoing commercial development & 7 & 26 \\
\hline \multicolumn{3}{|l|}{ Known uses of test*: } \\
\hline Clinical & 9 & 33 \\
\hline Research & 15 & 56 \\
\hline Don't know & 8 & 30 \\
\hline \multicolumn{3}{|l|}{ Require licence for research activities: } \\
\hline Yes, without exception & 6 & 22 \\
\hline Yes, except academic researchers & 6 & 22 \\
\hline Yes, royalty-free & 3 & 11 \\
\hline No & 12 & 44 \\
\hline \multicolumn{3}{|l|}{ Enforcement of patents*: } \\
\hline Intend to enforce & 18 & 67 \\
\hline No, too troublesome/expensive & 9 & 33 \\
\hline Suspected infringement & 5 & 18 \\
\hline Mailed notices of infringement & 3 & 11 \\
\hline Brought lawsuit & 1 & 4 \\
\hline
\end{tabular}

for genes associated with breast and ovarian cancer, hereditary haemochromatosis, and spinocerebellar ataxia type 1 . Each has been exclusively licensed to companies that are, to various degrees, restricting the performance of testing services by other laboratories. Not all patent holders are following this model. One such exception is the University of Michigan, which is broadly licensing its patent issued in 1998 covering the $\Delta \mathrm{F} 508$ allele that causes cystic fibrosis.

We believe that public institutions and the US National Institutes of Health should not grant exclusive licences for 'upstream' technologies and basic knowledge such as disease-gene associations, particularly when discovered using public funds. Such patents should be available to all, like the fundamental Cohen-Boyer patent on recombinant DNA ( $\mathrm{K}$. Ku, personal communication and ref. 7). Licensees should be permitted to perform patented tests nonexclusively and to sublicense others who wish to practice the patented methods. Collection of a reasonable royalty will ensure that the financial rewards and incentives of the patent system are maintained ${ }^{8}$.

Anna Schissel ${ }^{\star}$, Jon F. Merz $\dagger$, Mildred K. Cho $\ddagger$ ${ }^{*}$ New York University School of Law, New York, New York 10012, USA

$\dagger$ Center for Bioethics, Department of Molecular and Cellular Engineering, and Center for Clinical Epidemiology and Biostatistics,

University of Pennsylvania, Philadelphia,

Pennsylvania 19104-3308, USA

$\ddagger$ Stanford University Center for Biomedical Ethics, Palo Alto, California 94305, USA
1. Thomas, S. M. et al. Nature 380, 387-388 (1996).

2. Thomas, S. M. et al. Nature 388, 709 (1997).

3. Cho, M. K. \& Merz, J. F. Nature 390, 221 (1997).

4. Merz, J. F. Clin. Chem. 45, 324-330 (1999).

5. Merz, J. F. et al. Mol. Diagnosis 2, 299-304 (1997).

6. White, T. J. in The Genetic Frontier: Ethics, Law and Policy (eds Frankel, M. S. \& Teich, A. H.) 199-208 (AAAS, Washington DC, 1994).

7. Beardsley, T. Nature 311,3 (1984)

8. Nature 399, 619 (1999).

\section{Parents need catch-up courses to boost careers}

Sir - You ask why there are so few women in science (Opinion, Nature 401, 99 \& 829; 1999). Discrimination and bias aside, the answer is because we are not men. Women can only follow a linear career path if they choose to have no children, or to put their children into full-time day care (if they can find it). Even highly motivated, intelligent women are often in conflict at work if, for example, they choose day care, or if they create large holes in their careers by taking time out to look after children.

At 37 years of age I will soon be finishing an MSc and starting an entry-level science job. I abandoned veterinary medicine early because of the incompatibility of an on-call schedule with family ties. The largest barrier that I currently face is how quickly a scientist's knowledge can become out of date. I do not feel that it is reasonable or possible for a professional to keep up to date while meeting the demands of a young family.

One solution would be to design a short programme, lasting less than a year, to bring parents up to date after they have had an extended leave (of greater than five years). This would at least qualify them for an entry-level position. I, by my own choice, have lost ten years on my 'career path'. As the average career is between 40 and 50 years in length, I will have to be more than outstanding to 'trickle up through the system'.

Wendy Powell

11 Whittaker Court, Guelph,

Ontario, Canada N1C 1G1

\section{Lacking cover}

Sir - I was very surprised to see the advertisement for Dictagene on the back cover of the 7 October issue of Nature. Nudity has its place, as I am sure you will agree. It was totally unnecessary for a company to advertise its expression systems and custom-made proteins by displaying two nude human beings. What is this supposed to signify? I thought Nature was beyond such crass advertisements and I hope this is not the first of many such unpleasant sights.

Vani Kalyanaraman

Department of Anesthesiology,

Washington University School of Medicine,

St Louis, Missouri 63110, USA 